DOI: $10.17516 / 1997-1370-0829$

УДК 81 '42

\title{
Siberia as a Trigger of Geopolitical Conflictogenic Media Discourse
}

\author{
Margarita D. Lagutkinaa , Irina S. Karabulatova*b, c, \\ Irina P. Savchuk ${ }^{d}$, Sofia V. Onina ${ }^{d}$ \\ and Murshida E. Nurgaliyevae \\ aPeoples' Friendship University of Russia (RUDN-university) \\ Moscow, Russian Federation \\ ${ }^{b}$ Peoples' Friendship University of Russia (RUDN-university) \\ Moscow, Russian Federation \\ ${ }^{c}$ Moscow Institute of Physics and Technology (MIPT) \\ Moscow, Russian Federation \\ ${ }^{d}$ Ugra State University \\ Khanty-Mansiysk, Russian Federation \\ 'Toraighyrov Pavlodar State University \\ Pavlodar, Kazakhstan
}

Received 23.08.2021, received in revised form 30.08.2021, accepted 14.09.2021

\begin{abstract}
The article reveals the influence of manipulative tactics in the media discourse on the public consciousness of the peoples of different countries regarding such a huge territory as Siberia. The authors analyze the historical, sociological, and psycholinguistic aspects of the functioning of the geopolitonym Siberia in the geopolitical conflictogenic media discourse within the framework of the linguistic-informational model of Siberia in the modern media discourse on the material of different structural languages. The selection of sources was based on the method of contextual analysis with an emphasis on the implicit content of the media image of the region, the descriptive method, the method of cultural interpretation, content analysis. Information wars use the image of Siberia as the center of the matrix of conflict-prone media discourse to increase attention to events in Russia and accentuate geopolitical manipulations in the public consciousness. The authors give the concept of a media matrix for understanding the cognitive side of media images of a geopolitical topoobject, such as Siberia. The media matrix of geopolitonyms consists of linguoinfornems, being implemented in linguoinformational steps in the media discourse. The media image of Siberia is diverse, being realized in evaluative linguistic systems of different languages, based on scalable sociostereotypes about Siberia. The authors show what the mythologized and realistic perception of the image of Siberia is based on, how it is interconnected with the tasks of geopolitics, influencing success in intercultural communication. The research is aimed at understanding linguistic universals
\end{abstract}

(C) Siberian Federal University. All rights reserved

* Corresponding author E-mail address: karabulatova-is@rudn.ru

ORCID: 0000-0003-2830-6274 (Lagutkina); 0000-0002-4228-3235 (Karabulatova); 0000-0002-2611-7499 (Savchuk); 00000003-1419-0717 (Onina); 0000-0003-4893-5545 (Nurgaliyeva) 
in the perception of geopolitonyms. The article is of interest to specialists in the field of linguistics, psychology, journalism, history, cultural studies, sociology, and political science.

Keywords: media matrix of mass media, Siberia, conflict, linguoinformational model, linguoinformnema, geopolitonym, linguoinformational steps, media discourse.

This paper was financially supported by Ministry of Education and Science of Russian Federation on the program to improve the competitiveness of Peoples' Friendship University of Russia (PFUR University, RUDN-university) among the world's leading research and education centers.

Research area: linguisctics.

Citation: Lagutkina, M.D., Karabulatova, I.S., Savchuk, I.P., Onina, S.V., Nurgaliyeva, M.E. (2021). Siberia as a trigger of geopolitical conflictogenic media discourse. J. Sib. Fed. Univ. Humanit. soc. sci., 14(10), 1436-1454. DOI: 10.17516/1997-1370-0829

\title{
Сибирь как триггер геополитического конфликтогенного медиадискурса
}

\author{
М.Д. Лагуткина ${ }^{a}$ И.С. Карабулатоваб,в \\ И.П. Савчукг, С.В. Онинаг, М.Е. Нургалиевав \\ аРоссийский университет дружбы народов \\ Российская Федерачия, Москва \\ ${ }^{6}$ Российский университет дружбы народов \\ Российская Федерачия, Москва \\ ${ }^{8}$ Московский физико-технический институт (национальный университет) \\ Российская Федерация, Москва \\ 'Югорский государственный университет \\ Российская Федерачия, Ханты-Мансийск \\ ¿Павлодарский государственный университет \\ имени С. Торайгырова «Торайгыров Университет» \\ Казахстан, Павлодар
}

\begin{tabular}{l}
\hline Аннотация. В статье раскрывается влияние манипулятивных тактик в дискурсе \\
СМИ на общественное сознание народов разных стран относительно такой огромной \\
территории, как Сибирь. Авторы анализируют исторические, социологические \\
и психолингвистические аспекты функционирования геополитонима Сибирь \\
в геополитическом конфликтогенном дискурсе СМИ в рамках лингвоинформационной \\
модели Сибири в современном медиадискурсе на материале разноструктурных языков. \\
Отбор источников происходил с опорой на метод контекстуального анализа с акцентом \\
на неявное содержание медийного образа региона, описательный метод, метод \\
культурной интерпретации, контент-анализ. Информационные войны используют \\
образ Сибири в качестве центра матрицы конфликтогенного медийного дискурса для \\
усиления внимания к событиям в России и акцентуации геополитических манипуляций \\
в общественном сознании. Авторы дают концепцию медиаматрицы для понимания
\end{tabular} 
когнитивной стороны медийных образов геополитического топообъекта, каким является Сибирь. Медиаматрица геополитонимов состоит из лингвоинфорнем, реализуясь в лингвоинформационных шагах в дискурсе СМИ. Медиаобраз Сибири многообразен, реализуясь в оценочных лингвистических системах разных языков, исходя из масштабируемых социостереотипов о Сибири. Авторы показывают, на чем основано мифологизированное и реалистичное восприятие образа Сибири, как оно взаимосвязано с задачами геополитики, влияя на успех в межкультурной коммуникации. Исследование нацелено на понимание лингвистических универсалий в перцепции геополитонимов. Статья представляет интерес для специалистов в области лингвистики, психологии, журналистики, истории, культурологии, социологии и политологии.

Ключевые слова: медиаматрица СМИ, Сибирь, лингвоинформационная модель, лингвоинформнема, геополитоним, лингвоинформационные шаги, медиадискурс.

Исследование было поддержано Министерством образования и науки Российской Федерации по программе повышения конкурентоспособности Университета Дружбы народов России (РУДН) среди ведущих мировых исследовательских и образовательных центров.

Научная специальность: 10.02.00 - языкознание.

\section{Introduction}

During the development of Siberia in the XIX century. and XX century. young people, inspired by the slogans of the Soviet government in the printed press, went to Siberia, seeking to conquer the mystical land of the unknown and to prove themselves. Siberia has been associated with powerful symbols of darkness. So, V. G. Kartsev in his «Essay on the history of the peoples of North-Western Siberia» (Kartsev, 1937) describes and gives reproductions of lithographs, which depict Siberian aborigines in the form of animal-like people, dog-headed people (psoglavs - in Russian), etc.

Such positioning actualized archetypal ideas about Siberia as a gateway to Hell, the world of Death and Cold, and about Siberian peoples as representatives of a different nature opposed to ordinary people (Beloglazova, Kabakchi, 2020; Evseeva, Zhmakina, 2020; Grevnev, 2019; Karabulatova et al., 2014; Khairullina et al., 2015; Moskalyuk, Grishchenko, 2020; Mushkina, Bitner, 2021; Sayfulina et al., 2013; Vasil'eva, Dmitrieva, 2021;), which creates a fertile ground for nurturing conflicts on the «friend-foe» axis and «center - periphery» (Nemirovskaya, 2020; Skovorodnikov, et al., 2019; Sowińska, T. Dubrovskaya, 2012). In this regard, the cultural phenomenon of «folklore» pseudo-linguistic research on Siberian topics actualizes the prescientific methodology, contributing to the additional mythologization of Siberia in the world of human civilization, which also becomes the subject of scientific research (Savchuk, 2021; Terskikh, Malenova, 2015; Tyupa, 2002). «So, the results of previous research cannot serve today as a pretext for defending irrationalism that renounces thinking» (Huebner, 1996: 265).

Researchers note that recently the concept of «trigger» has become widely used, moving from the field of psychophysiology and medicine to other branches of scientific knowledge to designate a certain combined complex of the national picture of the world stored in the operative memory and background knowledge of an object, subject, event and action that with the manifestation of one of the elements of this complex, the remaining parts of the symptom complex are actualized (Ruzhentseva et al., 2020; Korolyova, 2021). This term was especially actively used in journalism and politics (Ardila, 2019; Carvalho, de \& Mesquita, 2021; Korolyova, 2021). At the same time, in the exact sciences, a trigger is a mechanism that forms two stable values of a signal at the input-output and is capable of abruptly changing these values due to 
external directional influence, which makes it possible to use a trigger in machine learning as a memory element (Kostomarov, 2019).

The globality of the toponym Siberia for human civilization is due to the multidimensional associative space of chthonicity in society. In classical cognitive modeling, the study of any conceptual category begins with the formation of a frame-type knowledge structure, and in our case, in the form of a toponymic synopsis (toponymic scenario) (the term of I. S. Karabulatova, 2002). First, such trends as «The Beginning» and «The End», «Life» and «Death», «Purgatory» and «Transformation» are clearly expressed here, which acquired a «second wind» in the apocalyptic era of the pandemic (Karabulatova et al., 2021).

The main ideas of this type are presented in the cognitive theory of metaphor (Lakoff, Johnson 2004). The result of this analysis is an opportunity to draw a conclusion about the typical ways of understanding these categories when perceiving the toponym Siberia, which are actualized in the geopolitical conflictogenic media discourse as an integral part of the linguistics of modern information and psychological warfare (the term of the Krasnoyarsk school-A. P. Skovorodnikov et al., 2019) in the confrontation between Russia and the West.

We are talking about Siberia as a geopolitonym, since it is not just a toponym, but a designation of a historical, cultural, and socio-political name of a territorial entity as a geopolitical subject Examples of geopolitical subjects are widely known at the level of countries, regions, historical regions: EU, Russia, Crimea, Caucasus, Kuban, Saryarka, Siberia, Brittany, Ireland, Xinjiang, Volhynia, Bavaria, Galicia, Sicily, Corsica, etc.

The geopolitonym Siberia does not just form a virtual image of the region in the media discourse but acts as a multidimensional construct of the linguistic picture of the world in the «producer - recipient»system. Onomasts under the geopolitonym understand the names of countries, regions, significant historical areas that have an impact on human awareness in the civilizational context (Madieva, 2010).

At the same time, the construction of a particular geopolitical media structure uses cognitive means of forming communicative meanings of predictable speech behavior, which also becomes the subject of scientific discussions in different countries (Savchuk et al., 2019; Luna Morales Xochiquetzal, 2008; Nijiati et al., 2020; Qin, Uccelli, 2019).

The representation of Siberia as an important strategic topoobject in the modern media discourse is due to the high degree of significance of this territory in the layouts of modern world, federal and regional geopolitics, in determining the locus of Siberia in the mythologized picture of the world of a modern native speaker in the actualization of mass media discourse.

\section{Materials and methods}

The mythologized space of the semantics of the toponym Siberia has a syncretic character, and therefore synergetics has become the defining methodological principle in this study. The toponym Siberia itself is considered as a geopolitonym through the prism of linguistic tools associated with the methods of related scientific disciplines (political science, psychology, journalism, sociology, history, folklore studies, psycholinguistics, etc.).

The research material is heterogeneous, the key point of selecting the material for analysis was the orientation of the publication on the topics of Siberia with an explicit or implicit provocation of the conflict in society. The catalog of such publications amounted to more than 4,000 articles extracted from the open access of the Internet, which allowed us to group the material by podcasts: 1) socio-political events; 2) cultural life, art events, cinema; 3) sports events; 4) economic events; 5) natural disasters, flora and fauna; 6) legends, legends, folklore of the ethnic groups of Siberia and other peoples about Siberia; 7) old and new mythology about Siberia; 8) real historical events and pseudo-history; 9) discoveries, scientific life of Siberia and attempts to devalue achievements.

Based on the above, we believe that an integrated approach is the most acceptable for the analysis of the geopolitical conflictogenic discourse of the conceptual space «Siberia». We have included in the methodology of the analysis of the geopolitonym Siberia as a trigger of the media discourse such methods as: 1) defi- 
nitional analysis with an emphasis on identifying explicit signs of the geopolitonym Siberia in the conflictogenic mass media discourse as a source of potential danger to society on the basis of primary and secondary interpretation of data; 2) the method of contextual analysis in order to determine the implicit content of the media image of Siberia as a trigger point; 3 ) the descriptive method; 4) the method of content analysis of monitoring the communicative system of the conflictogenic geopolitical media discourse.

\section{Results}

The media image of Siberia is a topooriented multi-layered model of the terrain for the recipients of the media discourse. Researcher O.N. Sorokina proposed the concept of an information model of images of countries on the example of China (2007), in which the linguistic component remained undeveloped, although it was and remains dominant in the media discourse.

The conflictogenic media discourse, as a rule, is provocative, for this purpose it actively uses manipulems (the term I. P. Savchuk, 2021) to control the reactions of society to this or that information. It should be said that manipulations with geopolitonyms are not so rare, they demonstrate the importance of a geo object for society (Martynenko, Ilina, Kupriyanova, 2019).

For example: «Sohu (China): is Siberia lost by China still possible to return? I regret to inform you that this is impossible» (15.11.2019, https://inosmi.ru/social/20191115/246230265. html); «Phoenix (China): Siberia was conquered by several hundred people! How did Russia with such a small population conquer such huge territories?» (15.08.2019, https://inosmi.ru/social/20190815/245635239.html); «The New York Times (USA): The Chinese are flocking to the Siberian Lake Baikal - and this worries the locals» (06.05.2019, https://inosmi. $\mathrm{ru} /$ social/20190506/245035734.html).

So, in the publication of «Phoenix» (China), in the reprint of the Russian portal InoSMI, it is indicated: «After the Little Ice Age, Siberia was exhausted, the Cossacks and soldiers met only weak nomadic tribes on their way, who were practically unable to resist. After the Russians appropriated these territories and invented the machine gun and wire fences, the Siberian farmers lost any opportunity to change the current situation. Russian missionaries also played a big role in this» $(15.08 .2019$, https://inosmi.ru/social/20190815/245635239.html).

At the same time, Siberia is represented as a victim of the expansion of the tsarist government, almost as an ownerless and deserted space, which fully coincides with the point of view of Siberia both in the West and in the East. We find in the publication such expressive lexemes and expressions as (Siberia) is exhausted, weak nomadic tribes, to appropriate territories, to lose the opportunity, conquered Siberia, etc. At the same time, the text of the publication itself comes into conflict within itself. On the one hand, Siberia is represented by weak nomadic tribes. On the other hand, Siberian farmers were colonized by Cossack detachments and detachments of missionaries. While the nomadic and sedentary lifestyles are opposed to each other in historical development. However, the note is constructed in such a way as to cause an internal conflict in the recipient of this information.

When S. Cohen proposed the hypothesis about the interdependent behavior of political actors on the world stage (Cohen, 1971), he proceeded from the fact that the verbal-paraverbal geopolitical behavior of countries would reflect this interchangeability based on the established relations between the countries - variable players. The researcher concluded that geographical or geopolitical thinking is based on the principle of spatial differentiation, so the mobility of differentiation of political phenomena depends on the location, which is the essence of political geography and geopolitics.

Siberia as a trigger of the conflictogenic media discourse is realized using linguoinforneme through the structure of the linguoinformational step in the space of the linguoinformational model. We propose the concept of a linguoinforneme, by which we understand the technique of constructing a media image of a subject or object in a particular accentological assessment, based on a social order. Contradictory media images of an object or subject 
create variability in the interpretation of the «semantic aura» of a geopolitonym in the media discourse, exerting their impact as a «potentially dangerous discourse» (Karabulatova, 2020: 4). Thus, the linguoinforneme of Siberia constructs a media image of the territory depending on the point of view on the «Siberian problem» of a particular state in a deliberately planned emotionally expressive one.

For example, the Siberian theme is relevant for the northern regions of Kazakhstan, which were founded as fortified garrisons and villages of the Siberian Cossack army, on the site of which large cities later grew. First, these are Kokshetau, Pavlodar, Kostanay, Petropavlovsk, which began to provide a dialogue between the Kazakh Steppe and the Russian Forest (Karabulatova, Koyshe, Gultyaev, 2013), cultivating national cadres for indigenous peoples, among whom the percentage of illiteracy reached $80 \%$ (Burdina, 2007). At the same time, the pre-revolutionary national newspapers of the local peoples of Siberia and Northern Kazakhstan also actively introduced a linguistic-information model aimed at the growth of ethnic and socio-cultural selfawareness (Khayretdinova, 2012).

In the context of modern political games both in Russia and in Kazakhstan, the issues of identification of the population of these cities, the use of» language patrols», attribution of the cities and territories themselves acquire a new urgency and become a potentially dangerous conflictogenic discourse in the context of ethnic trauma of the Kazakhs due to the tsarist policy of acculturation (Lyubichankovsky, 2019; Osipov et al., 2016). At the same time, the question invariably arises: where does Siberia end and the Kazakh Steppe begin? As indicated by a group of scientists, under the leadership of the Academician of the Russian Academy of Sciences G. V. Osipova, the consequences of this ethnotrauma are still actively used in the conflictogenic media discourse, actualizing the associative fan in the mental picture of the world of the peoples of the former tsarist Russia (Osipov et al., 2016).

Back in Soviet times, the Russian psychologist O.K. Tikhomirov was the first to point out the existence of phenomena of a subjective- objective order, which allowed him to introduce the concept of «value-semantic structure of the situation». The value-semantic structure of the situation, according to O.K. Tikhomirov, contains a characteristic of the effect of human interaction with objectively specified conditions (Tikhomirov, 1972, 1974). We believe that the value-semantic structure of the situation determines the conflictogenicity of mass media discourse. In addition, we believe that it is impossible to determine the potential danger of a discourse without considering the psychological parameters of the value-semantic structure of the situation that encourages the submission of information from one point of view or another.

The value-semantic structure of the situation itself affects the choice of a particular linguo-phoneme in mass media discourse, since the linguo-phoneme designates specific methods of manipulating the public consciousness of recipients, therefore, the lexical and semantic repertoire of the linguo-phoneme is always biased by a social order, unlike the cognitive metaphor, which more characterizes the author's language style.

At the same time, the creation of a clear scheme for analyzing the media matrix of the image of the country creates successful prerequisites for the development of a full-fledged classifier for further training of neural networks (Karabulatova, 2020 b) not only in terms of differentiating the system of interpretations of potentially dangerous discourse, but also in the context of the subsequent calculation of the predictive level of potential dangers for the recipient of the media discourse.

The analytical perception of the media image of Siberia in multilingual media discourses has been actively promoted in recent years from the position of the pragmatic potential of the linguoinforneme, i. e., assumptions about the typical features of the impact on the addressee during perception by the recipient. We believe that the pragmatic potential of the linguoinforneme underlies the linguistic interpretation and determination of the differences between fake, deepfake, post-truth and truth, which are indicated by Yekaterinburg researchers (Chudinov et al., 2019). 
Thus, the linguoinformational model of media discourse used is implemented in linguoinfornems using the strategy of linguoinformational steps. Linguistic and informational models of the representation of Siberia in foreign media discourses emphasize the geopolitical interests of other countries in relation to Siberia and Russia. So, when the Chinese media, publishing materials in Russian, turn to the image of Siberia, they proceed from the traditional hieroglyphic model «China is the Middle state», or «the center of the world», and «Siberia is the outskirts, the periphery of the Middle state». Hence such publications as «Why did China lose Siberia?», «Can China return Siberia?», etc. As researchers from Yekaterinburg under the leadership of A.P. Chudinov rightly point out, rhetorical questions are one of the leading signs of a trigger in geopolitical discourse (Ruzhentseva et al., 2019). In addition, the conflictogenic geopolitical discourse widely uses euphemisms, as if polemizing with «opponents» on the geopolitical world stage.

When we set the task of identifying trigger zones in the conflictogenic mass media discourse, we face the need to identify the specific meaning of the lexical unit used in the analyzed text segment. For example: What are the borders of Siberia as a territory in the author's understanding? Do these borders coincide in the modern territory of Siberia? Who does the author call Siberians? Does the author of the text use marking words-characteristics based on ethnicity: Russians / Ukrainians / Caucasians/ Kazakhs/ Yakuts/ Chinese, etc.? Are there any indications of social signs: a reindeer herder/ professor/ teacher/ mother/ drug addict/ oil worker/ student, etc. in a specific text? What signs characterize this lexeme, causing cognitive dissonance in recipients (such as: "Crimea is yours; Siberia is ours»; "The Siberian ripper tortured and killed schoolgirls in his apartment. His mother helped him in this»; "An eighth-grader stabbed the deputy director of a school near Novosibirsk», «In furs, but without underwear: how did Siberians differ from other women in Russia», "Why did a student of a Siberian college decide to kill his abusers», «An Omsk student is forced to climb a birch tree to study remotely», etc.
It is impossible not to agree with those researchers who note the polycode nature of capacious proper names, which contain a certain alpha and omega of human civilization. Thus, according to V.I. Postovalova, «the main feature of the interpretation of the beginning and the end in the Orthodox worldview is that these categories are not thought of here as abstract meanings, but as 1) specific names - the Names of God (Beginning, End, Beginningless, Infinite, etc.), as well as 2) semantic components of specific situations-realities, mythologies, events, etc. (creation of the world, Parousia, or the Second Coming of Christ, Judgment, Kingdom, etc.)» (Postovalova, 2002: 620). Geopolitonym Siberia occupies one of the central places in the eschatology of the Russian and European worldview, since it refers to a specific space, the mythological world of the Russian spirit, and the mythological world of the transcendental secrets of European civilization.

Thus, in the Russian language consciousness there is an opposition: Russia-Siberia, which is an echo of the opposition of Russia and Siberia as Tartary/Tartarus. Thus, a special place is occupied in the plots by the «Tatar/ Tartarland», which is located at the opposite pole, being opposed to everything Russian, it is the habitat of «enemies of foes, hefty Tatars, evil Tatar young warriors». «The conspiracy of a brave man who goes to any war» describes the battles with the Tatars - with gentiles, warriors who are famous for their cruelty, bravery, supernatural invulnerability: «You, mighty heroes, kill the Tatars, fill the entire Tatar land; and I would be safe and sound because of you. I go to the bloody Tatar/ Tartar Army, I beat enemies and foes; and I would be safe and sound». The Kremlin, which is not only in Moscow, but also in Siberia, the former capital of the Tobolsk province, now in one of the cities of the Tyumen region - Tobolsk, acts as a stronghold that can protect from all enemies. The first layer of associations is associated with flint, in fact, the etymology of the word is different: «Kremlin - flint, kremnik is old. and krom (from kromit, kromlenoe mto), detinets, inner fortress, fortress inside the city; a wall with loopholes, gates, towers, protecting the most important part of the city, the pal- 
ace, the treasury» (Karabulatova, Bondarets, 2005:138).

On ancient maps, the territory located beyond the Ural (Riphean) Mountains was designated only as Tartarus. It is known that an indispensable part of the mythocoordinates of European civilization is «tar-tar», or «tartarary». Tartar - borrowing from the Greek. language, was considered the lower part of the underworld-Hades, representing the dark abyss in the depths of space, was sometimes identified with Hades. There are always whirlwinds raging around Tartarus, it is surrounded by a triple layer of darkness and an iron wall (or three copper walls). The iron (or copper) gate of Tartarus is the creation of Poseidon. These iron gates can also be correlated with the Ural Mountains.

In Tartarus was the dwelling of Nikta/

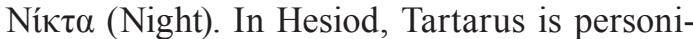
fied and is considered one of the first four gods. So, in the ancient tradition, Tartarus was described as a certain space located in the very depths of space, below Hades - the kingdom of the dead; it is not just fenced off by an iron / copper wall, but the night surrounds it in three rows. Even the gods are afraid of Tartarus because everything that falls into Tartarus disappears irrevocably, because there is no way back from there.

In modern Russian, the expression «to fall into the tartars» means to disappear, to perish (Klyaus, 1997: 136). It is this last, metaphorical meaning, that is realized in conspiracy texts in binding and in exile, in curses, etc. The description of Tartar repeats the information of myths, for example in «Prayer when someone mocks in the house»: «the gates are copper..., and iron shackles, (...) and the bonds of darkness are held in tartars, binding him (the snake)» (Karabulatova, Bondarets, 2005: 138).

In the context of modern history, the geopolitical role of Siberia as the sacred topos of Eurasia is central. From here come the «vessels» of oil pipelines connecting Europe and Asia. Here are the main natural reserves and resources of the entire planet. And «in this sense, the new mythological and political slogan of the United Russia, emphasizing that «Here is the heart of Russia!» is no longer just a metaphor coming from the seemingly coincidental outlines of the Tyumen region with a human heart, but a text with a deep meaning that makes us think about the mystical role of each small homeland in the fate of the big homeland» (Fedorova, Koyshe, Karabulatova 2012: 194).

This ancient toponym Siberia evokes lively reactions in most people living in different parts of our big planet, as a kind of designation of an otherworldly, mysterious, unreal space where the spiritual power of the Earth-Gaia is formed, where the «mysterious Russian soul» is maximally manifested (Fedulov et al., 2015). This space is mythologized as much as possible due to the remoteness from the center and the lack of knowledge about this territory.

Based on the stability of the mythologized perception of Siberia, in the Russian and European media discourse, Siberia is positioned as a territory of mysticism, sacredness, secrets, prohibitions. In this connection, the first place is occupied by the linguoinformational model «Siberia as an unknown secret», which exploits such linguoinfornemes as «Siberia as a frontier between the real world and the unreal world» (Evseeva, Zhmakina, 2020), «Siberia as a world reserve of lost knowledge» (Karabulatova, Fedorova, Saifulina, 2014), «Siberia as an enchanted world» (Kartsev, 1937; Kuznetsova, 2009), «Siberia - the other world». It is believed that supposedly only in Siberia the primordial knowledge is preserved, there are hidden resource sources and sacred «places of power», special people live, etc. (Karabulatova, 2008: 57-58), which imposes its own specifics on the perception of their own identity among Siberians (Grevnev, 2019; Evseeva et al., 2020). The linguoinformational model «Siberia as an unknown mystery» places the multilayered onomamifologeme Siberia in the center of linguoinforneme, which acts as a «poetics of space» with a significant share of fiction with the help of linguoinformational steps for the implementation of a mythological synopsis.

The mythologeme of the geopolitonym Siberia organizes around itself a specific mental space with a dominant expressive-emotional component, which is reflected in phraseological units and paroemias (Vassilenko, 2015), asserting the fabulousness, sacredness of this 
place: «Siberia is mother, and the Urals is father»; "Volga is mother and Don is Father, and Siberia is aunt»; «ice Siberia», «send to Siberia»; «Siberian bogatyr», "Siberian witch», «Siberian herbalist», "strong as a Siberian», «Siberian healer», «Siberian shaman», «Caucasian longevity and Siberian health», etc.

All these stable expressions reinforce the link «Siberia as a world reserve of lost knowledge», in which the Siberian acts as a special cultural hero who lives and acts according to the magical laws of a fairy tale (Propp, 1998). Therefore, in the modern media discourse, the hero's presence in Siberia, the hero's stay in Siberia is one of the mandatory attributes of the mythological halo since it gives the hero of the publication an aura of being chosen. The conflictogenicity of such a discourse is formed from the opposition of the hero and the main environment (the hero-deliverer-the king, the vizier, the king, etc.).

The resonant story of the Siberian shaman A. Gabyshev is embedded in the same paradigm, which has about 80 thousand news reports as of January 2021, and the BBC has created several documentaries about him (each of them has over 500 thousand views on YouTube). We refer such stories not to the genre of informational documentary discourse, but to mockumentary (pseudo-documentary) as one of the types of modern information warfare, «a completely or partially fictional product» that creates the illusion of realism (Zelvensky, 2008).

Mockumentaries go in a single bundle with the media discourse, increasing the impact on the recipient, since they aim to cause a wide public response, «shake up» public sentiment. In these news reports, the Siberian shaman A. Gabyshev is also depicted as a lone hero, led by Heaven, to fight the forces of Evil: «The Siberian shaman is coming to Moscow!», «The Yakut shaman is going to expel Putin», «Shaman Gabyshev has returned. What Putin is afraid of», «"' Violence is not allowed, even over a demon.» How a shaman from Yakutia went to expel Putin and did not reach», «A Yakut shaman who went to «expel Putin» was detained and taken to a mental hospital», «Special forces stormed the house of a Yakut shaman who promised to expel Putin», «Shaman Gabyshev was going to Moscow again», etc.

Therefore, it is not surprising that they began to be perceived as a kind of reincarnation of folk heroes who already existed in the people's memory. All these heroes have already been «registered» in the internal picture of the world of public consciousness, since such images as the Russian ataman Ermak, the Tatar khan Yedygei, the Ukrainian Robin Hood - Ustin Karmelyuk, the Tatar heroine Suzge are recorded in the national picture of the world.

In the XXI century, new names joined this cohort: the Siberian shaman Alexander Gabyshev actualized the mythologeme «Siberian sorcerer», imprinted in the public consciousness thanks to the Siberian sorcerer and healer Grigory Rasputin, a native of the Tobolsk province. Rasputin's name is widely known not only in Russia, but also in the West. His name became a household name, and the dark story of the death of a sorcerer and a seer entered the mythologized picture of the world. According to legend, G. Rasputin warned that the tsarist empire would collapse if members of the royal family were involved in his, Grigory Rasputin's, murder. Similar statements are made by the Irkutsk shaman A. Gabyshev. The way of the demonstrated behavior also strengthens the spiritual continuity between these sorcerers: the Tobolsk sorcerer G. Rasputin walked from Siberia to the capital of Russia to St. Petersburg, and the modern Irkutsk shaman A. Gabyshev also walked to the capital of Russia - Moscow.

The stories of modern cultural heroes mythologized by the public consciousness, coupled with the theme of Siberia, began to unfold in the media discourse as a mythologized discourse, resembling a biopic on the theme of the 11 steps of a fairy-tale hero in a fairy tale by V. Ya. Propp (1998). The inability of the official authorities to work with mass archetypes leads to an increase in the level of conflictogenicity of the media discourse and prohibitions, which increases the degree of discontent in society.

Despite the fact that the sub - regions of Siberia form their own linguoinfornems, which are promoted in the media discourse: «Ugra the birth of a circumpolar civilization» (Pra- 
solova, 2010), they find little response, since they are actively exploited only by representatives of government bodies, self-government and parties as a key component: «The survival strategy of the district (in the KhMAO, a very capacious concept is used for this - «the birth of a circumpolar civilization"»")) began with the realization of the main thesis...» (Moshechkov S. Ugra looks to the future // Russian Federation today, 2002, No. 1); "One of the most remote from the cultural and economic centers of the region in the eyes of contemporaries becomes the cradle of the future circumpolar civilization-the heiress of the most dynamic and positive features of the historical path of Russia» (Ugra: the birth of the circumpolar civilization. How to equip the North? // Vestnik, 2004, No. 4). The use of this linguoinforneme became the basis for the creation of historical, patriotic and tourist routes in the regions (Fedulin, Minaev, 2014).

The new conditions for the development of territories force us to look at the region as a commodity that needs to be sold profitably, hence the positioning of Siberia as the successor of the Soviet friendship of peoples in the countries of the post-socialist camp, implementing the linguoinforneme «Siberia as a brotherhood»: «Wydarzenie zostało zorganizowane $z$ uwzględnieniem narodowych tradycji, zwyczajów i kultury Polaków zamieszkujących terytorium Kraju Krasnojarskiego posługujących się językiem polskim» (JUBILEUSZ DOMU POLSKIEGO W KRASNOJARSKU， 25.12.2020, http://www.rodacynasyberii.pl/aktualnosc/538); «Ukrainians in Siberia: how the Ukrainian community lives in Irkutsk» (Irkutskinform, 04.12.2020, https://irkutskinform.ru/ukrainczy-v-sibiri-kak-zhivetukrainskaya-obshhina-v-irkutske/); "Germans in Siberia: colonists, special settlers and Russians» (Taiga.info, 13.12.2020, https://tayga. info/162593); «The State Duma deputies outraged Nur-Sultan, who reminds: Western Siberia has always been a place of settlement of Kazakhs, and Orenburg is their first capital» ("«They live on Russian lands»: is the territory of present-day Kazakhstan a gift to Russia?», 20.12.2020, Businessonline, https://www. business-gazeta.ru/article/493040).
In this regard, in the Russian and European media discourse, Siberia is often positioned as a kind of miracle, therefore, the linguistic information model «Siberia as a miracle» is implemented in the linguistic information system «Siberian miracle as a source of success», occupying a key position. The lexeme «miracle» means «something amazing, surprising with its extraordinary nature» (Shvedova, 2011: 1098), so the «Siberian miracle» is described with a high degree of expression and emotional saturation. For example: «Siberians are nuggets. Who develops talents in children and why?» (Argumenty I facty, 13.05.2016); «Siberians are lazy when they do not feel competition, especially when their life reaches a pleasant stability; but if they find a Siberian, he is able to dramatically change his life even at 40 , even at 50 years old, and achieve success. The Siberian is led in this not by the desire to «defeat the enemies», but by a bright practical dream» (Svobodnaya Pressa, 27.09.2010).

The linguoinforneme «Siberian miracle as a source of success» actualizes the demonstration of certain superpowers, non-standard solutions that are perceived as a miracle in different spheres of life (new technologies, sports, medicine, economics, technology, culture, agriculture, etc.). This linguoinforneme is supported by a bizarre mythologization of the image of Siberia in the minds of recipients because Siberia itself is located at a considerable distance from many countries of the world and is considered a territory of secrets and mysticism. For example: «A Siberian who was paralyzed as a child became a fitness trainer» (Komsomolskaya Pravda, 10.06.2021); «A Siberian makes shoes and jackets out of salmon - the Chinese wanted to buy the technology for half a million dollars: The story of a chemist who created fashionable things from fish waste» (NGS.ru, 29.07.2021). In the context of the geopolitical media discourse, Siberian health can act as a miracle, as well as the associated frames of medicine, flora, fauna, and health improvement systems.

In the linguoinformational models of the Western mass media discourse, the geopolitonym Siberia is at the center of a news message as a powerful mythologeme that causes 
the recipients to react with fear, the inevitability of evil, death, disease, and cold. So, in so many publications, the very stay in Siberia is equated with imprisonment, to a kind of mystical purification.

For example: «Siberia gets used to the cold surprisingly quickly: the Yakut horse does not mind the frost of 55 degrees» (Helsingin Sanomat, Finland, 31.12.2016); «Extreme reality show in Siberia: «Even rape and murder are allowed»") (Il Giornale, Italy, 17.12.2016). If we look at other linguistic information models with the geopolitonym Siberia in the media discourse, we will see that most publications have a negative connotation with a predominance of negative emotionally colored vocabulary, which allows us to classify them as potentially dangerous discourses, since they represent Siberia in a negative format.

The XXI century has become an epochmaking one for revealing the unique potential of sports in Siberia. After the 2019 World Universiade in Krasnoyarsk, the number of articles in the media about the specifics of the «Siberian sports miracle» is increasing exponentially: «The Siberian miracle. How did our young curlers win international recognition?» (Arguments and facts in Eastern Siberia, 18.12. 2020).

The linguoinformational model «Siberia as a space of forbidden knowledge and mysticism» is actualized in the following linguoinfornems: «Siberia as a center of forbidden knowledge», "Siberia as a source of littlestudied», "Siberia as a threat to humanity», «Siberia as the salvation of mankind».

Thus, the linguoinforneme « Siberia as a threat to humanity «is contrasted with the linguoinforneme»Siberia as the salvation of humanity». The linguoinforneme "Siberia as a threat to humanity» itself positions Siberia as a region with a dominant of all kinds of threats to the world in various spheres of life. First, this concerns the appearance of voids and sinkholes due to oil and gas production, deforestation, the awakening of unknown prehistoric viruses and deadly pathogens due to the melting of permafrost, etc. The conflict-prone media discourse will present the image of Siberia as something demonic, inexplicable, and irresistible, inspir- ing an irrational fear of the unknown and of Russia, including, therefore, any achievement of Siberia, any "breakthrough» in any area is considered not as a success, but as the conquest of positions, living space from someone else.

With the help of the linguoinforneme « $\mathrm{Si}$ beria as a threat to humanity», a threatening and dangerous image of Siberia is progressively introduced using bright, emotionally colored vocabulary and rich images with the help of linguoinformational steps. for example: «The prediction of the witch from Siberia came true», «The Krasnoyarsk sorcerer killed in Spain was resurrected in his homeland two months later», «Siberian shamans: killing with a word», etc. The result of such a strategy is the introduction of the idea that Siberia as a threat contains a potential danger to the development of civilization, meaning, and, the Western type of civilization. However, psychologically, this linguoinforneme is just an unconscious fear of misunderstanding the ethnocultural specifics of Siberia, as well as the fear of assimilation due to the powerful economic and cultural influence of Siberia on other countries and regions. The linguoinforneme «Siberia as a threat» acts as a statement of the fact of the deep dichotomy of the image of Siberia with the media images of other territories that have a significant impact on the world stage (Germany, Russia, the USA). Hence the desire of individual states to establish international control over the Siberian territories, or to annex them in some way. For example: «The USA was preparing to buy Siberia for $\$ 3$ trillion» (https://udipedia-news.ru/view/new?utm campaign $=2681 \&$ utm content $=\mathrm{df} 267876$ c9be-4de9-99fc-59906c1b3816\&utm s o u r c e $=44199 \&$ u t m m e d i $\mathrm{um}=104 \& \operatorname{sid} 6=10870803 \&$ templates show id $=41 \& \operatorname{sid} 9=$ view\&uid=86ade $616-104 \bar{b}-43 \mathrm{c} 1-$ $8 f 8 e-4 c 22552 b 8579)$; «Siberia of the Middle Kingdom: why China claims Russian territories» (Arguments of the Week, February 24, 2021); "Which countries believe that Siberia should not belong to Russia, Rambler reports» (Next: https://weekend.rambler. $\mathrm{ru} / \mathrm{read} / 42654132 /$ ?utm content $=$ weekend media\&utm_medium=read_more\&utm source=copylink); ««Why Siberian?»: Eliz- 
abeth II's unexpected decision puzzled the Russians» (Tsargrad, 24.11.2020).

Linguistic and informational steps to implement the «Siberian threat» support in the minds of recipients the image of Siberia, which is likened to a separate subject that determines the emotion of the threat. This image is actualized with the help of expressions: the awakened deadly virus (as one of the symbols of the coming Apocalypse), the mysterious petroglyphs of the Kuyussky grotto, the gate to hell, the Tunguska glade, the cave of the black devil (to denote the forbidden anomalous places of Siberia as places of manifestation of Evil in Western culture), etc.

First, the linguistic-informational model exploits the geopolitical myth with the focus of the recipients 'attention on achieving a certain conditional «emotional bottom» with the subsequent successful overcoming of the problem when leaving this state of hopelessness. This is designed not just to distract attention from some urgent situation, but to release the internal forces of a person to recreate a full-fledged sense of the possibility of overcoming a negative situation. On the one hand, it seems to be a good goal, but on the other hand, we are dealing with a social danger, which was pointed out by A.N. Kanev, warning about distortions in the ethno-national Renaissance (Kanev, 2009).

The process of decoding and interpreting the conflictogenic mass media discourse about Siberia aims to test each hypothesis according to the context, and only then it becomes possible to establish the meaning of a particular word and utterance. The process of text interpretation in linguistics, as in psychology, is often considered as a one-sided process of perception, while, unlike the psychological approach, the main attention is paid to the linguistic personality of the recipient communicant, while the speech producer is practically ignored.

\section{Discussion}

Modern researchers consider the trigger conflict-causing mass media discourse through the prism of the policy of «soft power» without considering purely linguistic tools, focusing primarily on the features of extralinguistic fac- tors (Barabash et al., 2019; Musolff, 2006; Nye, 2011; Nikitina, 2021; Kazakova-Apkarimova, 2014). A certain role is played using artificial intelligence in the recognition of negative content, which causes interest in conflict-prone political mass media discourse to identify a mechanism for promoting negative and ambiguous stereotypical images of countries and regions, especially in a situation of political instability.

Various issues of conflictogenic political discourse are considered in the works of leading scientists in the field of political linguistics, media linguistics, psycholinguistics, and cognitive linguistics (Dzyaloshinsky, 2012; Evseeva, 2020; Chudinov et al., 2019; Sheigal, 2000; Lakoff, 2004; Wodak, Boukala, 2006; Zheltukhina et al., 2020).

These studies set an algorithm for a fullfledged scientific analysis of the "soft power» policy in the image of Siberia, offering verified methodological tools and appropriate approaches to the selection of material (Barabash et al., 2019; Budaev, 2016; Chudinov et al., 2019).

We were guided by the theory of stereotyping (Lippman, 2004) to create clusters of parametrizations of linguistic-informational models and linguistic information in the context of positioning the image of Siberia, because this theory opens new opportunities for social and linguistic understanding of the political stereotype as such and its structure, including in the context of geopolitical imagemaking (Zamyatin, 1999; Tokbulatova, 2019; Skovorodnikov, 2020).

At the same time, the very development of problems of representing the image of Siberia correlates with the mechanism of representing the Caucasus, China, and Russia in media discourses, since it is based on theoretical studies on the semiotics of the ethnolinguinformational space (Dyganov, 2010; Niyazova, 2007; 2021; Khayretdinova, 2012). However, a distinctive feature is the specific use of linguoinfornemes, which include features of the representation/ inclusion of the media image of the region and / or country in the ethno-linguistic and information space. The linguoinforneme «Siberia as the center of the unknown» updates tourist routes, which is reflected in the publications of 
researchers (Terskikh, Malenova, 2015). The Siberian space again and again excites research minds, aiming at understanding the role of Siberia in the Russian language consciousness through the prism of non-fiction literature, which also traces the actual linguoinforneme introduced with the help of mediadiscourse (Tyupa, 2002).

«Emotional swings» are a characteristic feature of conflictogenicity, arousing interest from the audience, so mass media discourse swings the attention of recipients, throwing out the maximum number of hormones of joy and success, distorting the perception of reality as such. Political scientists see this as a source of separatist sentiments aimed at separating Siberia from Russia, the Urals from Russia as independent states (Kazinik, Tkachev, electronic resource).

The strengthening of emotional swings in the linguistic-informational model in the conflictogenic mass media discourse goes through the dynamic overcoming of fear. Such, for example, in our opinion, are provocative publications about the Siberian People's Republic, the creation of groups and communities with this name in social networks (for example, the social network «VKontakte» shows that the community «Siberian People's Republic» has about 300 participants who publish information and calls for the separation of Siberia from Russia).

Such statements cause fears among state structures and law-abiding citizens as a real threat to the state, the region, their own lives with the intensification of the fear of death and inevitable changes. At the same time, the psychophysiological reactions of recipients are like reactions to opioids, in connection with which the perception of reality is catastrophically transformed, but the recipient experiences the most vivid emotions (Niyazova, 2021). The use of this forbidden technique gets the audience hooked on receiving increasingly strong stimuli's, rocking them to revolutionary sentiments, which we saw during the collapse of the USSR, when geopolitonymic myths were used to strengthen separatist sentiments. For example: «Ukraine is the breadbasket of the USSR: enough to feed everyone!» etc. (Savchuk, 2021). However, this positioning of exclusivi- ty in relation to a particular region or republic within the USSR was due to the introduction of the ideas of the collapse of the Soviet Union with the exploitation of ethnocentrism (Khairullina et al., 2015; Sayfulina et al., 2013). The mosaic of ideas about Siberia, the abundance of interpretations of the name itself forced researchers to carefully approach the secondary analysis of scientific literature and etymologies (Beloglazova, Kabakchi,2020). At the same time, the geopolitonym Siberia in the conflictogenic discourse of the media continues to occupy a central place in the dissemination of invariants of the onomastic myth (Karabulatova, Niyazova, 2014). Currently, we are observing certain elements of this strategy in relation to the regions of Russia, which poses a danger to the geopolitical unity of the country.

\section{Conclusion}

Our research has demonstrated that background concepts and symbols vary in the composition of precisely fixed concepts when constructing the media image of Siberia in a conflict-prone media discourse, transforming the picture of the world of a modern recipient. The geopolitical image of Siberia is formed from a fan of associatively connected ideas about the end and beginning of the world, so the media image of this region looks quite mosaic, but it is understandable for decoding in the minds of recipients. The linguoinforneme can be conditionally compared with a complex of cognitive metaphors, but it selects only those metaphors for which there is a social order. At the same time, the media discourse space is aimed at solving pragmatic problems of maximum audience involvement. When comparing the definition of a cognitive metaphor, in the definition given by E. McCormack (1990: 363 ), and the linguoinforneme in the media discourse, we can find differences in the scope of concepts separately. The cognitive metaphor orients us to the process of understanding the implementation of the linguoinforneme. The linguoinforneme is a structural element of the mass media matrix of geopolitonyms as a producing media image of countries and regions (such as: China, America, Altai, Crimea, Ireland, Siberia, etc.). 
The linguoinforneme itself, as a building element of the conflictogenic media discourse, contains specific techniques for manipulating the public consciousness of recipients. In addition, the lexical and semantic repertoire of linguoinforneme is always biased by a pro-government social order (or anti-government), in contrast to the cognitive metaphor, which acts as a characterological feature of a person's individual language style.
The linguoinforneme makes the very scheme of analyzing the media matrix of the image of a specific territory clearer, creating successful prerequisites for developing a prototype of a multidimensional classifier for further training of neural networks both in terms of differentiating the system of interpretations of a potentially conflictogenic discourse, and in the context of subsequent calculation of the predictive level of potential dangers for the recipient of such a media discourse.

\section{References}

Ardila, J. (2019). Impoliteness as a rhetorical strategy in Spain's politics, Journal of Pragmatics, 01, 140, 160-170, DOI: 10.1016/j.pragma.2018.11.017

Beloglazova, E.V., Kabakchi, V.V. (2020). Siberia / Sibir / Sibir' / Sybir: what's in a name? J. Sib. Fed. Univ. Humanit. Soc. Sci., 13(12), 1902-1913. DOI: 10.17516/1997-1370-0693

Burdina. E. L. (2007). Pozitsiya rossiyskogo pravitel'stva po voprosu «Inorodcheskogo» obrazovaniya v nachale XX veka [The position of the Russian government on the issue of «alienian» education at the beginning of the XX century] in Voprosy obrazovaniya [Education issues], 3, .278-287. URL: https://cyberleninka.ru/article/n/pozitsiya-rossiyskogo-pravitelstva-po-voprosu-inorodcheskogo-obrazovaniya-v-nachalexx-veka (дата обращения: 21.08.2021). [in Russian]

Budayev, A. V. (2016). «Myagkaya sila» BRIKS: novyye gorizonty i izmereniya sotrudnichestva [«Soft power» BRICS: new horizons and dimensions of cooperation.]. Moscow: Pero, 191 p. [in Russian]

Carvalho, B. H. C. P. de, \& Mesquita, W. A. B. (2021). Quilombola Aesthetic as a Political Articulation. Asian Journal of Sociological Research, 5(2), 1-8. Retrieved from https://www.globalpresshub.com/ index.php/AJSR/article/view/1178

Chudinov A.P., Koshkarova N.N., Ruzhentseva N.B. (2019). Lingvisticheskaya interpretatsiya rossiyskoy politiki cherez prizmu feyka, dipfeyka, postpravdy [Linguistic interpretation of Russian policy through the prism of fake, deepfake, post-truth] in Journal of the Siberian Federal University. Series: Humanities, 12, 10, 1840-1853.

Cohen, S. B. (1971). Geography and Politics in a Divided World. Oxford, 351 p.

Dzyaloshinskiy, I. M. (2006). Manipulyativnyye tekhnologii v SMI [Manipulative technologies in the media]. Moscow: Humanitarian Institute, 44 p. [in Russian]

Dyganov, A. G. (2010). Informatsionnoye prostranstvo kak faktor kachestva zhizni naseleniya: avtoreferat dis. ... kandidata sotsiologicheskikh nauk. [Information space as a factor in the quality of life of the population: abstract of thesis. ... candidate of sociological sciences]:]. - Kazan: Kazan. (Privolzh.) feder. University, 22 p. [in Russian]

Evseeva, I. V. (2020). Kommunikativnaya situatsiya «obsuzhdeniye zakona o neuvazhenii k gossimvolam» v aspekte informatsionno-psikhologicheskogo protivoborstva [The communicative situation «discussion of the law on disrespect for state symbols» in the aspect of information and psychological confrontation.] in Lingvistika informatsionno-psikhologicheskoy voyny: collectiv.monography [Linguistics of information-psychological war: monograph]. Book. III.; ed. prof. A.P. Skovorodnikov. Krasnoyarsk: Sib. Feder. University, p. 242-258. [in Russian]

Evseeva, I. V., Kopnina, G. A., Eremina, E. V., Verenich, T. K., Bashkova I. V. (2020). Russian open education centre «Siberia.ru»: the conceptual bases and prospects for development. Journal of Siberian Federal University. Humanities and Social Sciences, 13, 12, 1952-1961.

Evseeva, I.V., Zhmakina, I.S. (2020). The concept of Stolby Nature Reserve in the aspect of linguoimageology. J. Sib. Fed. Univ. Humanit. Soc. Sci., 13(12), 1914-1926. DOI: 10.17516/1997-1370-0694. 
Fedorova, E. A., Koyshe, K. K., Karabulatova, I. S. (2012). Mifolingvisticheskaya interpretatsiya khoronima «Sibir'»: tyurksko-mongol'skaya pertseptsiya v yevropeyskom prostranstve [Mytholinguistic interpretation of the khoronym «Siberia»: Turkic-Mongolian perception in the European space] in Nauchnoye obozreniye. Seriya 2. Gumanitarnyye nauki. Lingvistika [Review. Series 2. Humanities. Linguistics]. Moscow, 6, 192-199. [in Russian]

Fedulin, A. A., Minayev, V. A. (2014). Novyye voyenno-istoricheskiye marshruty: regional'nyye aspekty sozdaniya [New military-historical routes: regional aspects of creation] in Service +, 14-21, DOI: 10.12737/6462 [in Russian]

Fedulov, A. M., Karepova, S. G., Karabulatova, I. S., Akhmetova, B. Z., Istamgalin, R. S. (2015). The Phenomenon of «Russian Soul» as a Reflection of Traditional Russian Conservatism: New Theoretical and Methodological Approaches and Ordinary Perception of Conservatism in Mediterranean Journal of Social Science, 6, 6, 3, 113-121, DOI: 10.5901/mjss.2015.v6n6s3p113

Huebner, K. (1996). Istina mifa [The truth of the myth]. Moscow: Republic, 448 p. [in Russian]

Galinskaya, T. N. (2013). Ponyatiye mediaobraza i problema yego rekonstruktsii v sovremennoy lingvistike [The concept of a media image and the problem of its reconstruction in modern linguistics] [Electronic resource] in Bulletin OSU, 11 (160). Access mode: http://vestnik.osu.ru/2013_11/16.pdf.15.10.2015 [in Russian]

Grevnev, V. M. (2019). Mental'nyye i psikhologicheskiye osobennosti sibiryakov kak tsennostnyye modusy regional'noy identichnosti (na primere Krasnoyarskogo kraya) [Mental and psychological features of Siberian both modes of regional identity value (for example of Krasnoyarsk region)] in Vestnik kul'tury $i$ iskusstv [Bulletin of culture and arts], 4 (60), 84-93. [in Russian]

Kanev, A. N. (2009). Mifologicheskoye mirovozzreniye $v$ kul'ture obskikh ugrov: filosofskokul'turologicheskiy analiz: avtoref. Dis. ... kand. filosof. nauk [Mythological worldview in the culture of the Ob Ugrians: philosophical and cultural analysis: abstract of dis. ... Cand. philosopher. Sciences]. Chelyabinsk: Chelyabinsk State Academy of Culture and Art, 23 p. [in Russian]

Karabulatova, I. S. (2008). Prognosticheskaya toponimika: transformatsiya toponimicheskogo prostranstva $v$ yazykovom soznanii nositeley russkogo yazyka [Prognostic toponymy: transformation of toponymic space in the linguistic consciousness of Russian speakers]. Tyumen: Pechatnik, 254 p. [in Russian]

Karabulatova, I. (2020 a) Possibilities of artificial intelligence in assessing the impact of potentially dangerous texts in modern news discourse: problem of statement Published online: 24 December 2020. International Scientific Forum «Issues of Modern Linguistics and the Study of Foreign Languages in the Era of Artificial Intelligence (dedicated to World Science Day for Peace and Development)» (LLT Forum 2020), 88, DOI:_https://doi.org/10.1051/shsconf/20208801001

Karabulatova I. S. (2020 b). Problemy sozdaniya tsifrovogo biblioteki dlya otsenki opasnogo tekstov (POT) v sovremennom novostnom diskurse [Problems of creating a digital library for the assessment of dangerous texts (DT) in modern news discourse] in Voprosy sovremennoy lingvistiki i izucheniya inostrannykh yazykov $v$ epokhu iskusstvennogo intellekta [Questions of modern linguistics and the study of foreign languages in the era of artificial intelligence: collection of articles]. Proceedings of the International Scientific Forum dedicated to the World Science Day for Peace and Development / ed. S. A. Kaskabasov, N. G. Valeeva. Moscow: RUDN, 3-12. [in Russian]

Karabulatova, I.S., Bondarets, Ye.A. (2005). Zagovor: imya sobstvennoye v sakral'nom diskurse znakharskoy praktiki [Conspiracy: a proper name in the sacred discourse of woodoo practice]. Tyumen: Felix, 368 p. [in Russian]

Karabulatova I. S., Koyche K.K., Gultyaev V.N. (2013). The Dialogue of Kazakh Steppe and Russian Forest: About the Character of Turkic-Speaking Linguistic Personality on the Territory of RussianKazakhstani Border-Zone in Middle-East Journal of Scientific Research 17 (7): 853-858, DOI: 10.5829/ idosi.mejsr.2013.17.07.12264

Karabulatova, I. S., Niyazova, G. M. (2014). Informonim kak svernutyy onomasticheskiy mif etnicheskoy identichnosti (na primere nazvaniy tatarskikh SMI) [Informonym as a folded onomastic myth of 
ethnic identity (on the example of the names of the Tatar media outlets)] in Bulletin of the Oryol State University, 5(40), 167-170[in Russian]

Karabulatova I. S., Fedorova E. A., Sayfulina F. S. (2014) A Linguo-Mythological Space of the Toponym «Siberia» in Contemporary Slavonic Linguistic Consciousness in World Applied Sciences Journal, 30 (9): 1134-1138, DOI: 10.5829/idosi.wasj.2014.30.09.14118

Karabulatova, Irina S., Lagutkina, Margarita D. and Amiridou, Stefania (2021). The Mythologeme «Coronavirus» in the Modern Mass Media News in Europe and Asia/Karabulatova, Irina S., // Journal of Siberian Federal University. Humanities \& Social Sciences 2021, 14(4): 558-567. doi: 10.17516/1997-13700742

Kartsev, V. G. (1937). Ocherk istorii narodov Severo-Zapadnoy Sibiri [Essay on the history of the peoples of North-West Siberia]. Moscow: Sotsetgiz, 132 p. Retrieved from: https://www.studmed.ru/karcov-vgocherk-istorii-narodov-severo-zapadnoy-sibiri_fdd4eee59da.html [in Russian]

Kazakova-Apkarimova, Ye. Yu. (2014). Ideologiya oblastnichestva kak faktor formirovaniya regional'noy identichnosti (na primere Sibiri i Urala) [The ideology of regionalism as a factor in the formation of regional identity (on the example of Siberia and the Urals)] in VyatSU Bulletin, 12, 46-52. [in Russian]

Kazinik, M., Tkachev, D. (2021) Pyatiminutnyy putevoditel' po sibirskomu separatizmu in Esquire. 15 let $v$ Rossii [A Five-Minute Guide to Siberian Separatism in Esquire. 15 years in Russia], [Electronic resource]. Retrieved from: URL: https://esquire.ru'relaxation/2172-5-min-siberia/ [in Russian]

Khairullina N. G., Karabulatova I. S., Shvedova M. F., Koyshe K. K. (2015). Tatars of Siberia: religious rebirth and identity problems in Terra Sebus: Acta Musei Sabesiensis, 7, 565-583, Retrieved from: available at [http://www.cclbsebes.ro/docs/Sebus_7_2015/30_KHAIRULLINA_alii.pdf]

Khayretdinova, A. M. (2012). Leksiko-semanticheskiye parametry nominativnykh yedinits etnolingvoinformatsionnogo prostranstva tyurkoyazychnykh SMI: na materiale tatarskogo, azerbaydzhanskogo i kazakhskogo yazykov: avtoreferat dis. ... kandidata filologicheskikh nauk [Lexico-semantic parameters of nominative units of the ethno-linguistic information space of the Turkic-language media: on the material of the Tatar, Azerbaijani and Kazakh languages: abstract of thesis. ... candidate of philological sciences]. Tobolsk: Tobolsk State Social and Pedagogical Institute named after D. I. Mendeleev, 22 p. [in Russian]

Klyaus, V.L. (1997). Ukazatel' syuzhetov i syuzhetnykh situatsiy zagovornykh tekstov vostochnykh i yuzhnykh slavyan [Index of plots and plot situations of conspiracy texts of the Eastern and Southern Slavs]. Moscow Naslediye, 462 p. [in Russian]

Korolyova, L. Yu. (2021) Comparative analysis of triggers in Russian and American political discourse in Research result. Theoretical and Applied Linguistics, 7 (1), 78-91. DOI: 10.18413/2313-8912-2021-7$1-0-7$

Kostomarov, K.V. (2019). Possibilities of using neural networks in the investigation of crimes in J. Sib. Fed. Univ. Humanit. Soc. Sci., 12(11), 2023-2030. DOI: 10.17516/1997-1370-0509

Kuznetsova, T. A. (2009). Tema Sibiri v periodicheskikh izdaniyakh Imperatorskogo Russkogo Geograficheskogo obshchestva vtoroy poloviny XIX - nachala XX vv.: avtoref. dis. ... kand. istor. nauk [The theme of Siberia in the periodicals of the Imperial Russian Geographical Society of the second half of the 19th - early 20th centuries: author. dis. ... Cand. history. Sciences]. Omsk: Omsk State Pedagogical University, 24 p. [in Russian]

Lakoff, George, Johnson, Mark (2004). Metafory, kotorymi my zhivem [Metaphors We Live] by Translation from English. Ed. and with a foreword. A. N. Baranov. Moscow: Editorial URSS, 256 p., ISBN5-35400222-2 [in Russian]

Lippmann, W. (2004). Obshchestvennoye mneniye [Public opinion]. Общественное мнение. Translation from English. T. V. Barchunov; ed. K. A. Levinson, K. V. Petrenko. Moscow: Institute of the Public Opinion Foundation, 328 p. [in Russian]

Luna Morales Hochiketzal (2008). Geopoliticheskiye ucheniya i geopoliticheskiy diskurs v zhurnalistike: na materiale publikatsiy v gazetakh «Vremya novostey», «Kommersant»», «N'yu-York Tayms» $i$ «El' Pais»: avtoreferat dis. ... kandidata filologicheskikh nauk [Geopolitical doctrines and geopolitical discourse in journalism: on the material of publications in the newspapers «Vremya novostei», «Kommersant», «New 
York Times» and «El Pais»: abstract dis. ... candidate of philological sciences]. Moscow: Moscow State University named after M. V. Lomonosov, 19 p. [in Russian]

Lyubichankovskiy, S. V. (2019). K istorii bytovoi akkul»turatsii kazakhov I tatr v Rossiiskoi imperii XIX veka [On the History of Domestic Acculturation of the Kazakhs and the Tatars in the Russian Empire of the 19th Century] in Izvestia Saratovskogo universiteta. Novaya seria. Istoria. Mezhdunarodnye otnoshenia [Izv. Saratov Univ. (N. S.), Ser. History. International Relations], 19, 3, 279-282. DOI: https://doi. org/10.18500/1819-4907-2019-19-3-279-282 [in Russian]

McCormack, E. (1990). Kognitivnaya teoriya metafory [Cognitive theory of metaphor]. Translation from English: A.D. Shmelev. In Teoriya metafory. Sbornik statey [Metaphor theory. Digest of articles]. Translation from English, French, German, Spanish, Polish. lang.; Introductory article and compiled by N.D. Arutyunova; general edition of N.D. Arutyunova and M. A. Zhurinskaya. Moscow: Progress, 358386. [in Russian]

Madieva, G.B. (2010). Imya sobstvennoye v kontekste poznaniya [Proper name in the context of learning], Almaty; Moscow: Kazakh national. university named after Al-Farabi, Institute of Linguistics RAS, 2nd ed., Rev. and add., 239 p. [in Russian]

Martynenko, I. A., Ilyina, A. Yu., Kupriyanova, M. E. (2019). Toponimiya Folklendskikh ostrovov skvoz' prizmu territorial'nykh sporov [Falkland Islands Toponymy through the Prism of Territorial Disputes] in Politicheskaya lingvistika [Political Linguistics], 2, 67-78 [in Russian]

Moskalyuk, M.V., Grishchenko, A.P. (2020). Siberian identity in traditions and innovations of art culture. J. Sib. Fed. Univ. Humanit. Soc. Sci., 13(6), 914-923. DOI: 10.17516/1997-1370-0615.

Muchkina, E. S., Bitner, M. A. (2021). Image of Siberia and Siberians in English: Linguistic Interpretation of Axiological Meanings. Journal of Siberian Federal University. Humanities \& Social Sciences, 14(4): 459-465, DOI: 10.17516/1997-1370-0733

Musolff A. (2006). Metaphor Scenarios in Public Discourse in Metaphor and Symbol, 1, 23-38.

Nemirovskaya, A.V. (2020). Subjective well-being and conflicting social identities in the frontier regions of Russia. J. Sib. Fed. Univ. Humanit. Soc. Sci., 13(9), 1541-1558. DOI: 10.17516/1997-1370-0662

Nijiati, A., Karabulatova, I., Yuan Lin, Sautieva, F. (2020) Problems of cognitive distortions in crosscultural communication when using automatic translation in the Russian Chinese dialogue. Published online: 24 December 2020. International Scientific Forum «Issues of Modern Linguistics and the Study of Foreign Languages in the Era of Artificial Intelligence (dedicated to World Science Day for Peace and Development)» (LLT Forum 2020) Volume 88, 2020. DOI https://doi.org/10.1051/shsconf/20208803004. Retrieved from: Problems of cognitive distortions in cross-cultural communication when using automatic translation in the Russian Chinese dialogue | SHS Web of Conferences (shs-conferences.org)

Nikitina, E. S. (2021). Smells of the Homeland or patriotic texts through the prism of psychosemiotics/ Elena S. Nikitina// European Proceedings of Social and Behavioural Sciences EpSBS. Edited by: Prof Dr Irina Savchenko. Published by European Publisher. Pages 678-683. DOI:10.15405/epsbs.2021.02.02.85

Niyazova, G.M (2007). Sovremennoye informatsionnoye prostranstvo: etnolingvofunktsional'nyy podkhod [Modern information space: ethnolinguofunctional approach]. Tyumen: Pechatnik, 190 p. [in Russian]

Niyazova, G.M. (2021). Mezhetnicheskiy konfliktnyy mediadiskurs v sovremennom elektronnoinformatsionnom prostranstve [Interethnic conflict media discourse in the modern electronic information space] in Mir nauki, kul'tury i obrazovaniya [World of Science, Culture and Education], 2 (87), 600-602, DOI: 10.24412/1991-5497-2021-287-600-602[in Russian]

Nye, Joseph S. (2011). The Future of Power. N. Y., 300 p.

Onina, S., Vyhrystyuk, M., Islamova, J., Baksheyeva, M., Dolzhenko, N., Chelak, E., \& Savchuk, I. (2020). National cultural characteristics of the Khanty's communicative behavior in stimulating speech acts. Amazonia Investiga, 9(25), 389-394. Retrieved from https://amazoniainvestiga.info/index.php/amazonia/article/view/1084

Osipov G., Karabulatova I., Shafranov-Kutsev G., Kononova L., Akhmetova B., Loskutova E., Niyazova G. (2016). Ethnic trauma and its Echo in today's mental picture of the world among the peoples of the 
post-soviet states: an interethnic conflicting discourse unfolding in Russian's ethnolinguistic information space. Central Asia and the Caucasus. Journal of Social and Political Studies, 17, 2, 87-94. http://www. ca-c.org/journal/2016/journal_eng/cac-02/10.shtml

Postovalova, V.I. (2002). Nachalo i konets v pravoslavnom mirosozertsanii [The beginning and the end in the Orthodox world outlook] in Logicheskiy analiz yazyka: Semantika Nachala i Kontsa [Logical analysis of language: Semantics of the Beginning and the End]. Moscow: Indrik, 608-632. [in Russian]

Prasolova, O. V. (2010). Formirovaniye imidzha regiona $v$ sredstvakh massovoy informatsii: na primere Khanty-Mansiyskogo avtonomnogo okruga - Yugry: avtoref. dis. ... kand. filol. nauk [Formation of the image of the region in the media: on the example of the Khanty-Mansiysk Autonomous Okrug - Ugra: author. dis. ... Cand. philol. Science]. Voronezh: Voronezh State University, 22 p. [in Russian]

Propp, V. YA. (1998). Morfologiya volshebnoy skazki. Istoricheskiye korni volshebnoy skazki [The morphology of a fairy tale. The historical roots of the fairy tale] in Sobraniye trudov V. Ya. Proppa [Collected works of V. Ya. Propp.] Comments by E. M. Meletinsky, A. V. Rafaeva. Compilation, scientific edition, textual commentary by I. V. Peshkov. Moscow: publishing house «Labyrinth», $512 \mathrm{p}$.

Qin, Wenjuan, Uccelli, Paola (2019). Metadiscourse: Variation across communicative contexts. Journal of Pragmatics, 01, 139, 22-39, DOI: 10.1016/j.pragma.2018.10.004

Ruzhentseva, N.B., Koshkarova, N.N., Chudinov, A.P. (2020). Triggery v diskurse vlasti i ikh otrazheniye v SMI [Triggers in discourse of power and their reflection in the media] in Yazyk $i$ cul'tura [Language and culture], 50, 99-114. DOI: 10.17223/19996195/50/8 [in Russian]

Savchuk, I. P. (2021). Evolyutsiya mifolingvisticheskikh kharakteristik geopolitonima Sibir' (na materiale sovremennykh SMI): dissertatsiya ... kandidata filologicheskikh nauk [Evolution of the mytholinguistic characteristics of the geopolitonym Siberia (based on the material of modern mass media): dissertation ... of a candidate of philological sciences]. Moscow: Peoples' Friendship University of Russia, 166 p. [in Russian]

Savchuk, I. P., Karabulatova, I. S. (2021). Mytholinguistic interpretation of the sacred geopolitonym Siberia as an «Overton window» in the military film discourse in Bulletin of the Adyghe State University, 1, 116-125 [in Russian]

Sowińska, A., Dubrovskaya, (2012). Discursive construction and transformation of 'us' and 'them' categories in the newspaper coverage on the US anti-ballistic missile system: Polish versus Russian view. Discourse \& Communication, 6 (4), 449-468.

Sayfulina F. S., Karabulatova I. S., Yusupov F. Yus., Gumerov I. G. (2013). Contemporary issues of textual analysis of Turkic-Tatar literary monuments of Western Siberia in World Applied Sciences Journal, 27 (Education, law, economics, language and communication): 492-496, DOI: 10.5829/idosi.mejsr.2013.27. elelc101

Sheigal, E.I. (2000). Semiotika politicheskogo diskursa [Semiotics of Political Discourse]. Moscow; Volgograd: Peremena, 367 p. [in Russian]

Shvedova, N. Yu (2011). Tolkovyy slovar' russkogo yazyka s vklyucheniyem svedeniy o proiskhozhdenii slov (82000 slov i frazeologicheskikh vyrazheniy) [Explanatory dictionary of the Russian language with the inclusion of information about the origin of words (82,000 words and phraseological expressions)]. Executive editor N. Yu. Shvedova. Moscow: Azbukovnik, 1175 p. [in Russian]

Smorgunova, V. Yu., Dorskaia, A.A., Chestnov, I.L. (2019). The legal regulation of Siberian peoples in the Russian Empire: the interplay between customary law and legislation. J. Sib. Fed. Univ. Humanit. soc. sci., 12(6), 932-938. DOI: 10.17516/1997-1370-0431.

Skovorodnikov, A.P., Kopnina, G.A., Kolmogorova, A.V. (2019). Information and psychological war linguistics as a research project at the Siberian Federal University: problems and achievements. J. Sib. Fed. Univ. Humanit. Soc. Sci., 12(10), 1904-1921. DOI: 10.17516/1997-1370-0495.

Sorokina, O. N. (2007). Yazykovaya realizatsiya obraza Kitaya kak informatsionnoy modeli $v$ sredstvakh massovoy informatsii SSHA: dissertatsiya ... kandidata filologicheskikh nauk [Linguistic implementation of the image of China as an information model in the US mass media: dissertation ... of a candidate of philological sciences]. Vladivostok: Far Eastern Federal University, 201 p. 
Sverkunova, N. V. (2002). Regional'naya sibirskaya identichnost': opyt sotsiologicheskogo issledovaniya [Regional Siberian Identity: The Experience of Sociological Research]. St. Petersburg: Research Institute of Chemistry, St. Petersburg State University, 192 p. [in Russian]

Terskikh, M.V., Malenova, E. D. (2015). Media image of the Siberian region (based on materials from modern American media) in Man in the world of culture, 3, 19-30 [in Russian].

Tikhomirov, O.K. (1972). Psihologiya i kibernetika [Psychology and Cybernetics] in USA: economics, politics, ideology, 7, 94-104 [in Russian]

Tikhomirov, O.K. (1974). Informacionnaya i psihologicheskaya teorii myshleniya [Information and psychological theory of thinking] in Voprosy Psihologii [Questions of Psychology], 1, 40-48 [in Russian]

Tokbulatova, Zh. E. (2019). Obraz Kazakhstana v Rossii po materialam SMI [The image of Kazakhstan in Russia based on media materials] in Izvestiya RAN. Seriya geograficheskaya [Proceedings of RAS. Geographic series], 5, 32-42. [in Russian]

Tyupa, V.I. (2002). Mifologema Sibiri: k voprosu o «sibirskom tekste» russkoy literatury in Sibirskiy filologicheskiy zhurnal [Siberian Journal of Philology], 1, 27-35. Retrieved from: https://www.studmed.ru/ tyupa-v-i-mifologema-sibiri-k-voprosu-o-sibirskom-tekste-russkoy-literatury_c946d11611b.html [in Russian]

Vasil'eva, S.P., Dmitrieva, L.M. (2021). Review of toponymic studies of Altai and Siberia in the anthropocentric paradigm. J. Sib. Fed. Univ. Humanit. Soc. Sci., 14(4), 478-488. DOI: 10.17516/1997-1370-0735.

Wodak, R., Boukala, S. (2015). European identities and the revival of nationalism in the European Union: a discourse historical approach in Journal of Language and Politics, 14:1, 87-109. DOI:10.1075/ jlp.14.1.05wod

Zamyatin, D. N. (1999). Modelirovaniye geograficheskikh obrazov. Prostranstvo gumanitarnoy geografii [Modeling geographic images. The space of humanitarian geography.]. Smolensk: Oikumena, 255 p. [in Russian]

Zheltukhina, M. R., Magomadova, T. D., Chervyakova, L. D., Korovina, S. G., Krivoshlykova, L. V., Nesova, N. M. (2020). Military Metaphor as Means of Modern Media Knowledge Communication: Functional, Lexical and Grammatical Aspects in Astra Salvensis, 1, 515-547. ISSN-E: 2393-4727 ISSN-L: 2344-1887 Full Text (Article № 32): https://astrasalvensis.eu/2020-2/

Zelvensky, S. (2008). Mocumentary: istoriya voprosa in 11.04.2008 [Session, 11.04.2008], [[Electronic resource]. Retrieved from: https://seance.ru/articles/mocumentary/ [in Russian] 